\title{
CYTOLOGICAL, HISTOLOGICAL AND MOLECULAR CHARACTERISATION OF TWO ISOLATES OF CUCUMBER MOSAIC VIRUS (CMV) IN EGYPT
}

\author{
Elsayed E. Wagih, Mohamed M. Zalat, Maha A. Kawanna
}

Department of Plant Pathology, Faculty of Agriculture, El-Shatby, Alexandria University, Alexandria, Egypt.

\section{A R T I C L E I N F O}

\section{Article History}

Received: January 15, 2021

Revised: February 27, 2021

Accepted: March 08, 2021

\section{Keywords}

CMV

Cytological studies

Histological studies

Purification

Phylogenetic analysis
A B S T RAC T

Two isolates of Cucumber mosaic virus (CMV), CMV-wild tobacco (from Alexandria governorate) and CMV-cucumber (from Kafr El-Sheikh governorate) were investigated in this study. Cytological studies on epidermal strips of Nicotiana glutinosa leaves separately infected with each isolate revealed the presence of viral crystalline inclusion bodies within the infected cells. Electron microscopy of ultrathin sections of CMV infected N. glutinosa leaves showed significant alterations in the shape and internal structure of chloroplasts. The cell wall had serrated edges in infected cells but was more severe in cells infected with CMV-wild tobacco isolate compared to those infected with CMV-cucumber isolate. CMV-cucumber isolate was partially purified from systemically infected leaves of $N$. glutinosa. The ratio $A_{260 / 280}$ was 1.0 and the concentration of the virus in the preparation was estimated using an extinction coefficient of $E_{260 \mathrm{~nm}} 0.1 \%, 1 \mathrm{~cm}=5$. Yield of purified virus was about 2.8 $\mathrm{mg} / 100 \mathrm{~g}$ fresh weight of infected N. glutinosa leaves. Electron microscopy of the purified preparation of CMV showed the presence of numerous spherical particles with a mean particle diameter of $28 \mathrm{~nm}$. Amplified real-time reverse transcriptionpolymerase chain reaction (qRT-PCR) product of coat protein gene of each isolate was purified and sequenced. Sequences of both isolates had been submitted to GenBank Database and ware assigned accession number (LT669766) for CMVcucumber isolate and (LT706517) for CMV-wild tobacco isolate. The sequences were edited using Chromas Pro. Version 1.34 software and compared with previously subgrouping of 27 isolates of the virus retrieved from the GenBank database. Both $\mathrm{CMV}$-wild tobacco and CMV-cucumber isolates were closely related to the isolate with the accession number AJ585086 with a similarity of $97.07 \%$ and $98.54 \%$, respectively, suggesting that the two isolates belong to subgroup II. According to the available literature, this is the first report in Egypt where CMV isolates belonging to subgroup II have been obtained.

Corresponding Author: Maha A. Kawanna

Email: mahakawanna@yahoo.com

(C) The Author(s) 2021.

\section{INTRODUCTION}

Cucumber mosaic virus (CMV) is a member of the family: Bromoviridae and genus: Cucumovirus (Sastry et al., 2019). CMV is one of the most economically important viruses infecting plants worldwide. The virus has probably the widest host range as it infects approximately 1200 plant species causing heavy economic losses (Zitter and Murphy, 2009). The genome of CMV consists of three positive sense, single stranded RNAs (RNA 1, RNA 2 and RNA 3) packaged in separate particles and a subgenomic RNA (RNA 4) encoded by RNA3 that is involved in encapsidation (Suzuki et al., 1991). Numerous strains of CMV have been reported from all over the world classified into two major subgroups, I and II, based on serology and 
nucleotide sequence homology (Owen et al., 1990; Hull, 2002; Sulistyowati et al., 2004), host reaction (Daniels, 1992), and restriction fragment length polymorphism (RFLP) (Sialer et al., 1999). These two subgroups, I and II, generally show about $75 \%$ sequence similarity, whereas strains in the same subgroup show $90-99 \%$ sequence identity (Takeshita et al., 2004). CMV subgroup I has been recently divided into IA and IB on the basis of gene sequences available for CMV strains and phylogenetic analysis (Roossinck, 2002). In Egypt, almost all isolates of CMV studied so far (Sofy and Soliman, 2011; Megahed et al., 2012; El-Borollosy and Waziri, 2013; Nour El-Din et al., 2013; Rabie et al., 2017) were found to belong to either subgroup IA or IB. According to the available literature, no work has so far been reported on the isolation of a CMV belonging to subgroup II in Egypt. The aim of the present investigation was, therefore, to find the natural variation exist among CMV isolates in Egypt and to elucidate their cytological, histological, molecular characteristics and phylogenetic analysis. Attempts were made to reveal the likely presence of CMV isolates belonging to subgroup II among those subjected to this study.

\section{MATERIALS AND METHODS}

\section{Virus source and maintenance}

Two isolates of CMV, CMV-wild tobacco isolated from Borg El-Arab (Alexandria governorate) and CMVcucumber isolated from Desok, (Kafr El-Sheikh governorate), isolated and identified by Wagih et al. (2021) were maintained on Nicotiana glutinosa which served as a source of the virus for subsequent studies.

\section{Mechanical inoculation}

Except otherwise stated, virus inoculum of each isolate was separately prepared by grinding infected leaf tissues $(1: 10, \mathrm{w} / \mathrm{v})$ in $0.01 \mathrm{M}$ sodium phosphate buffer, $\mathrm{pH} 7.0$ containing $0.5 \% 2$-mercaptoethanol using sterilised and pre-chillded mortar and pestle (Dheepa and Paranjothi, 2010). Leaves of $N$. glutinosa to be inoculated were first dusted with carborundum (600 mesh) then inoculated by rubbing using forefinger with a freshly prepared inoculum. Inoculated plants were labeled and kept under glasshouse conditions.

\section{Histological and cytological changes induced by CMV Examination of inclusion bodies by light microscopy} Crystalline inclusion bodies (CIB) were observed in the epidermal strips from the lower surface of $N$. glutinosa leaves infected with each CMV isolates (12 days post inoculation DPI) by following standard method (El-Baz, 2004; Megahed, 2008; Taha, 2010). Corresponding samples from healthy plants were also examined as a check.

\section{Examination of ultra-thin leaf sections by transmission electron microscopy}

Three small pieces (1x1 mm each) of fresh $N$. glutinosa leaves infected with either of two isolates of CMV (15 DPI) and a healthy control plants were separately cut out and fixed under vacuum in $2 \%$ glutaraldhyde and $2 \%$ paraformaldehyde in $0.05 \mathrm{M}$ cacodylate buffer $\mathrm{pH}$ 7.0) for 2 hours at room temperature, rinsed with the same buffer several times. The specimens were then post fixed in $2 \%$ Osmium tetroxide $\left.\mathrm{CsO}_{4}\right)$ in the same buffer at $4{ }^{\circ} \mathrm{C}$ for 2 hours. Samples were washed in the buffer and dehydrated at $4{ }^{\circ} \mathrm{C}$ through a graded series of ethanol and imbedded in Spurr's epoxy-resin. Ultrathin sections of $10 \mathrm{~nm}$ thickness were cut off by a glass knife of an LKB ultramicrotome and stained with $1 \%$ toluidine blue to select out by light microscopy the proper sections for electron microscopy. Sections were placed on grids and stained with $0.5 \%$ uranyl acetate for $15 \mathrm{~min}$ followed by lead citrate for $2 \mathrm{~min}$. before examination by a Jeol JEM-100ex electron microscope, Japan (Martelli and Russo, 1984; Medina et al., 2003).

\section{Purification of CMV}

CMV-cucumber isolate was purified from CMVsystemically infected leaves of $N$. glutinosa by the method described by Tomlinson et al. (1973) and applied by Ashby (1977) and Aglave et al. (2007) with some modifications. A portion of $100 \mathrm{~g}$ fresh infected leaves showing systemic symptoms were harvested 18 DPI then homogenised in ice-cold $100 \mathrm{~mL}$ of $0.5 \mathrm{M}$ potassium phosphate buffer ( $\mathrm{pH} 7.5$ ) containing $0.2 \mathrm{~mL}$ thioglycollic acid and 0.001M-EDTA (extraction buffer). The homogenate was squeezed and filtered through two layers of cheesecloth; the pulp scraped off the muslin was re-extracted in $50 \mathrm{~mL}$ of extraction buffer. An equal volume of diethyl ether $(1: 1, \mathrm{v} / \mathrm{v})$ was then added to the filtrate and stirred up for $20 \mathrm{~min}$, after which it was subjected to low-speed centrifugation (UNIVERSAL 32HETTICH) at $500 \mathrm{xg}$ for 15 minutes at $4{ }^{\circ} \mathrm{C}$. The aqueous phase (Lower) was aspirated and retained for $30 \mathrm{~min}$ at $20{ }^{\circ} \mathrm{C}$ to remove excess ether and the pellet was discarded. The whole mixture was centrifuged 
(UNIVERSAL 32-HETTICH) at $8000 \mathrm{x}$ g for $30 \mathrm{~min}$ at $4{ }^{\circ} \mathrm{C}$ after which the pellet was discarded and the supernatant retained followed by ultra-centrifugation to precipitate the virus from the clarified extract by centrifugation (OPTIMA XE- BECKMAN COULTER) at 35,000 xg for 120 min at $4{ }^{\circ} \mathrm{C}$. Pellets were re-suspended in $1 \mathrm{~mL}$ of disodium tetraborate buffer ( $\mathrm{pH}$ 9.0) containing of 0.005 M- EDTA and the preparation was stored at $4{ }^{\circ} \mathrm{C}$ for $20 \mathrm{~h}$ (overnight). The suspension was then subjected to lowspeed centrifugation at $500 \mathrm{xg}$ for $10 \mathrm{~min}$ at $4{ }^{\circ} \mathrm{C}$ and the supernatant was, further, centrifuged two times at $8000 \mathrm{x}$ $\mathrm{g}$ and $500 \mathrm{x} \mathrm{g}$, respectively for $15 \mathrm{~min}$ at $4{ }^{\circ} \mathrm{C}$. The supernatant containing the partially purified virus was withdrawn with a fine Pasteur pipette and transferred into a clean vial to be stored at $-20^{\circ} \mathrm{C}$. Virus identity and concentration were checked biologically by inoculating leaves of Chenopodium amaranticolor for local lesion development. The UV-absorption spectrum of the purified virus preparation was spectrophotometrically performed over the range of 200-320 nm wavelengths with $10 \mathrm{~nm}$ intervals using an ultraviolet spectrophotometer (Thermo Scientific, VISION pro ${ }^{\mathrm{TM}}$ ). The parameters, $\mathrm{A}_{260} / \mathrm{A}_{280}$ as well as virus concentration were estimated. Concentration of the virus in the preparation was determined as outlined by Noordam (1973) using an extinction coefficient of $\mathrm{E}_{260 \mathrm{~nm}} \mathrm{n}^{0.1 \%}, 1 \mathrm{~cm}=5$.

\section{Electron microscopy of CMV}

Formvar-coated nickel grids were floated on drops of purified CMV preparations for 5 minutes. After a rinse with distilled water, the grids were stained with $2 \%$ uranyl acetate and examined with a Jeol JEM-100ex electron microscope. Particles were examined at $60,000 \mathrm{x}$ direct magnification and their diameter measured.

\section{Detection by real-time reverse transcription- polymerase chain reaction (qRT-PCR)}

Total RNA was extracted from $100 \mathrm{mg}$ of $N$. glutinosa leaves infected with the isolates under investigation and an equal quantity of healthy plant leaves as control using GeneJet RNA Purification Kit ${ }^{\mathrm{TM}}$ (Thermo scientific Company, Canada) according to manufacture instructions. Total RNA was used for complementary DNA (cDNA) synthesis using Rotor-Gene $\mathrm{Q}$ (QIGEN, Company). Coat protein (CP) gene of CMV was amplified using one step RT-PCR kit (SnsiFastTM SYBER ${ }^{\circledR}$ Lo-ROX One-Step Kit, Bioline Reagents Ltd,
USA), according to manufacturer instructions. cDNA synthesis was carried out in a total volume of $20 \mu \mathrm{L}$ containing: $0.4 \mu \mathrm{L}$ RiboSafe RNase Inhibitor, $1 \mu \mathrm{L}$ each of the forward ( $5^{\prime}$ - TATGATAAGAAGCTTGTTTCGCGCA-3') and reverse primer (5'-TTTTAG CCGTAAGCTGGATGGACAACCC-3' (Dietzgen et al., 2001), $0.2 \mu \mathrm{L}$ of reverse transcriptase, $4 \mu \mathrm{L}$ of RNA template (about $50 \mathrm{ng}$ ), then the volume completed with $13.4 \mu \mathrm{L}$ DEPC- $\mathrm{H}_{2} \mathrm{O}$ RNase free. The reaction conditions of qRTPCR were as follows: one cycle of $45{ }^{\circ} \mathrm{C}$ for $10 \mathrm{~min}$ (reverse transcription), one cycle of $95{ }^{\circ} \mathrm{C}$ for $2 \mathrm{~min}$ (polymerase activation), 40 cycles of $95{ }^{\circ} \mathrm{C}$ for $5 \mathrm{sec}$ (denaturation), $60{ }^{\circ} \mathrm{C}$ for $10 \mathrm{sec}$ (annealing) and extension at $72{ }^{\circ} \mathrm{C}$ for $5 \mathrm{sec}$. The amplification product was re-amplified by the conventional PCR to obtain high yield of cDNA. PCR reaction was carried out using a thermal cycler (Primus 25 Advanced ${ }^{\circledR}$, Peqlab Company) in $25 \mu \mathrm{L}$ mixture containing: $12.5 \mu \mathrm{L}$ of Master Mix (MyTaq $^{\text {TM }}$ Red Mix), $0.5 \mu \mathrm{L}$ of each primer, $3 \mu \mathrm{L}$ of cDNA (template), $8.5 \mu \mathrm{L}$ of sterile nuclease-free distilled water. The initial denaturation was performed at $90{ }^{\circ} \mathrm{C}$ for 45 sec, followed by 40 cycles of denaturation at $94^{\circ} \mathrm{C}$ for 45 sec, annealing at $60{ }^{\circ} \mathrm{C}$ for $45 \mathrm{sec}$ and extension at $72{ }^{\circ} \mathrm{C}$ for $1 \mathrm{~min}$. PCR reaction was terminated by final extension at $72{ }^{\circ} \mathrm{C}$ for $10 \mathrm{~min}$. The PCR products were separated in agarose gel (1.5\%), stained with RedSafe ${ }^{\mathrm{TM}}$. Electrophoresis was carried out at 100 volts (Cleaver Scientific Ltd) for 20 minutes. DNA bands were visualized on a UV-transilluminator.

\section{Molecular studies}

Sequence analysis of CMV (cucumber and wild tobacco) CP gene

Nucleotide sequencing of the coat protein gene of each isolate was carried out on the corresponding purified PCR product using BigDye® Direct Sanger Sequencing Kit and sequencing product was purified using CentriSep spin column and resolved on an ABI PRISM® 3700 Genetic Analyzer at Sigma Scientific Services Company. The isolates were compared with the previously described sequences in the NCBI database using the BLAST program.

\section{Sequence alignment and phylogenetic analysis}

Pairwise and multiple DNA sequence alignment were carried out using ClustalW multiple sequence alignment program version 1.82 (http://www.Ebi.ac.uk/clustalw) (Thompson et al., 1994). Bootstrap neighbor joining tree 
was generated using MEGA programme version 6.0 (Tamura et al., 2013) by applying the neighborhood Joining method and the Kimura 2-parameter model (Kimura, 1980; Shevchenko et al., 2015). Sequences had been submitted to GenBank Database (CMV-cucumber, accession No. LT669766; CMV-wild tobacco has accession No. LT706517) were compared with the CP gene sequences of twenty seven CMV strains belonging to subgroup IA, IB and II obtained from GenBank Database (Verma et al., 2006; Sofy and Soliman, 2011), and the similarity was calculated using the Superimposed Image Analysis System (SIAS) software programme by pairwise method (http://imed.med.ucm.es/Tools/sias.html).

\section{RESULTS}

Characterisation of two Egyptian isolates of CMV (CMVcucumber isolate) and (CMV-wild tobacco isolate) was based mainly on the cytological, histopathological, U.V. absorption spectrum of the purified virus, qRT-PCR and phylogenetic analysis.

\section{Histological and cytological changes induced by CMV}

Careful examination of epidermal strips and ultrathin sections of $N$. glutinosa leaf tissues separately infected with either CMV-cucumber isolate, or CMV-wild tobacco isolate and phosphate buffer mock-inoculated healthy leaves, by both light microscopy and transmission electron microscopy, revealed the occurrence of a number of cytological and histopathological changes as described hereunder.

\section{Examination of inclusion bodies by light microscopy}

Epidermal strips of CMV-infected leaves of $N$. glutinosa, separately inoculated with the two test isolates, CMV-wild tobacco and CMV-cucumber, in addition to epidermal strip of phosphate buffer-inoculated leaves were prepared and stained with the mercuric bromophenol blue reagent and examined with light microscopy. Examination revealed the presence of crystalline inclusion bodies in infected cells (Figure 1). Such inclusions have never been observed in epidermal strips derived from healthy, phosphate buffer-inoculated leaves.
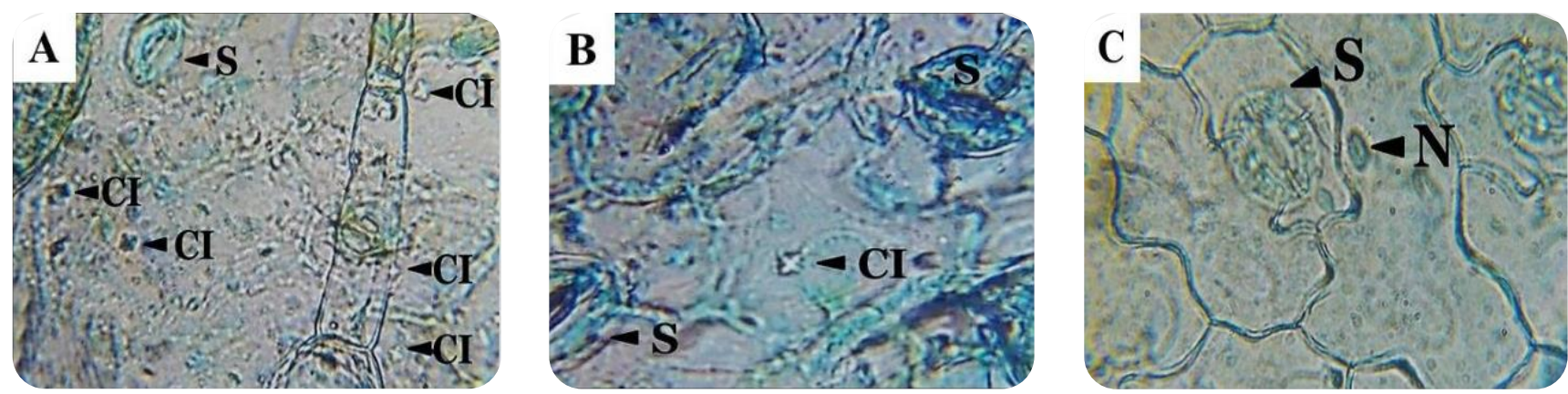

Figure 1. Light micrograph of a surface view of an epidermal strip of $N$. glutinosa infected with a CMV-wild tobacco isolate (A) and CMV-cucumber isolate (B), 15 DPI as compared to that of a healthy (control) specimen (C). Arrow heads point at crystalline inclusion bodies (CI), nucleus (N) and stomata (S). Magnification X400.

\section{Examination of ultra-thin leaf sections by electron microscopy}

Examination of ultra-thin sections of $N$. glutinosa leaves separately infected with either CMV-cucumber isolate or CMV-wild tobacco isolate and phosphate buffer mock-inoculated healthy leaves by transmission electron microscopy showed a large number of significant changes due to viral infection. In infected cells, chloroplasts assumed abnormal swollen shape, intergrana lamellae were disorganised and grana appeared loose and lacking integrity. Starch grains were either almost absent (Figure 2A) within chloroplasts from cells infected with CMV-wild tobacco isolate or reduced in size in cells infected with the CMV-cucumber (Figure 2B).

In some cells, swollen chloroplasts seemed to have ruptured as a result of CMV-cucumber isolate infection (Figure 2C). Such alterations were never observed in phosphate buffer mock-inoculated healthy specimen (Figure 2D). As to cell wall, CMV-wild tobacco isolate caused it to become serrated at both sides (Figure 3A) whereas serration was less obvious when CMVcucumber isolate was involved (Figure 3B). Phosphate buffer mock-inoculated healthy specimen showed no such changes (Figure 3C).

\section{Purification and electron microscopy} Absorption spectrum of the partially purified virus CMV-cucumber isolate was purified from $N$. glutinosa 
leaves showing systemic mosaic symptoms. When absorption spectrum over the range from 200-700 nm wavelength was performed, the ultraviolet absorbance of the purified virus preparation was found to be similar to that of nucleoproteins with a minimum at $220 \mathrm{~nm}$ and a maximum at $265 \mathrm{~nm}$. The ratio $A \quad 260 / 280$ was 1.0 . Concentration of the virus in the preparation was estimated according to Noordam (1973) using an extinction coefficient of $E_{260 \mathrm{~nm}} 0.1 \%, 1 \mathrm{~cm}=5$. The yield of purified virus was about $2.8 \mathrm{mg} / 100 \mathrm{~g}$ infected leaves. The partially purified preparation was tested for infectivity on C. amaranticolor as a diagnostic host which gave necrotic local lesions, 5 DPI.
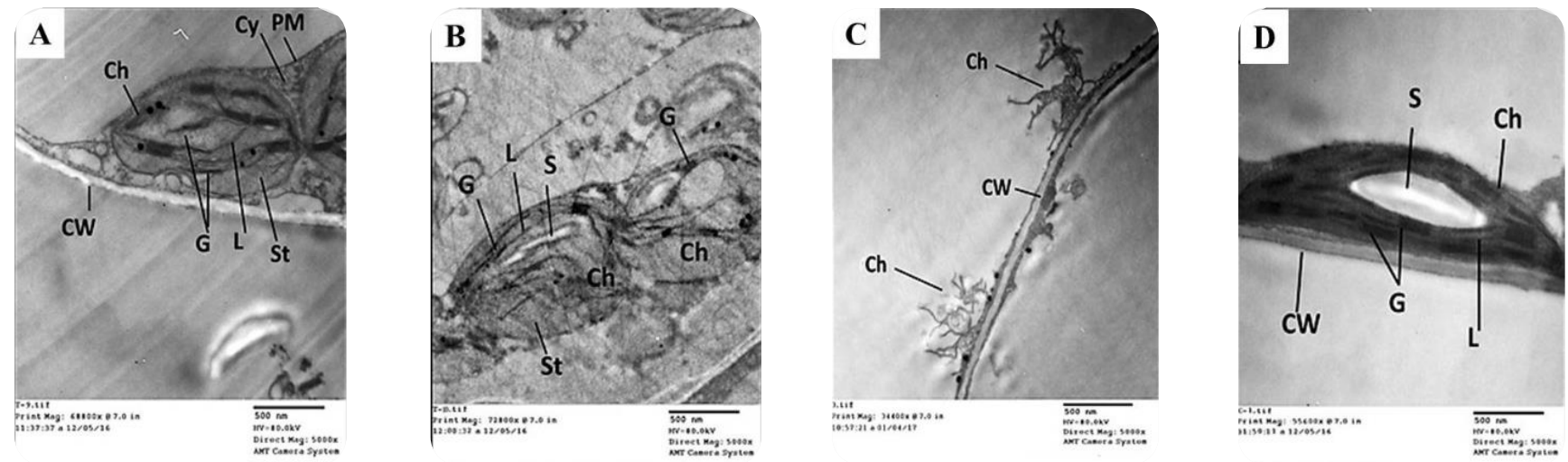

Figure 2. Transmission electron micrographs of ultra-thin sections of $N$. glutinosa leaves infected with CMV-wild tobacco isolate and CMV-cucumber isolate as compared to that of the phosphate buffer mock-inoculated leaves. In CMV-wild tobacco-infected leaves, chloroplasts were found swollen with degenerated grana and disrupted intergrana lamellae with the absence of starch grains (A). With CMV-cucumber isolate similar changes were observed, albeit with less amplitude and smaller size starch grains (B). Later, chloroplast membrane seemed to have ruptured and the whole structure erupted with lamellae remnants being left behind (C). In phosphate buffer mock-inoculated leaf cells, chloroplasts (D) were seen located close to the cell wall. They were assuming elliptical shape with well-developed grana and intergrana lamellae and accommodating large starch grains. Ch, Chloroplast; CW, cell wall; CY, cytosol; G, grana; L, lamella; PM, plasma membrane; S, starch grain; St: stroma. Scale bar $500 \mathrm{~nm}$.
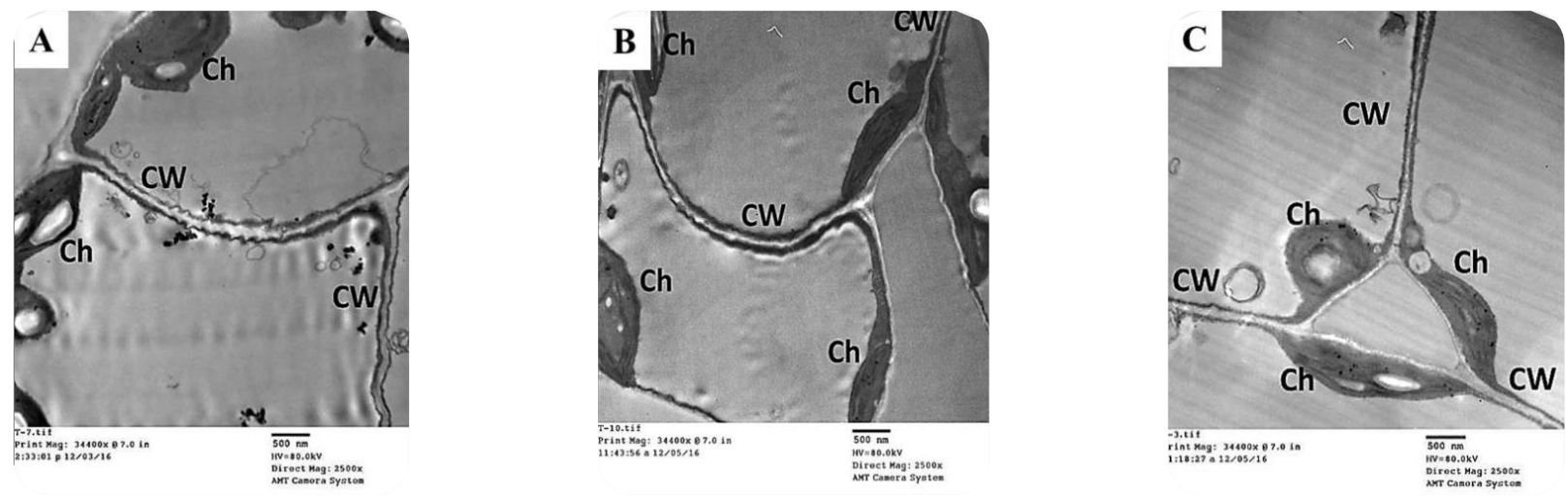

Figure 3. Transmission electron micrographs of an ultra-thin section of $N$. glutinosa leaf cells infected with the CMVwild tobacco isolate (A) showing serration of both sides of cell wall and those with CMV-cucumber isolate (B) where serration was less pronounced. Cells of phosphate buffer mock-inoculated healthy leaves (C) showed no such alterations. Ch, chloroplast; CW, cell wall. Scale bar, $500 \mathrm{~nm}$.

\section{Electron microscopy of CMV}

Electron micrographs of purified preparation of CMV revealed the presence of numerous isometric particles
(Figure 4). The modal size of particles was found to be $28 \mathrm{~nm}$ in diameter. 


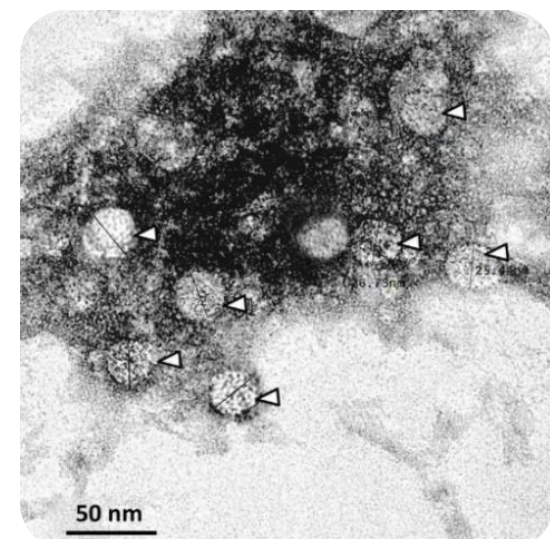

Figure 4. An electron micrograph of a partially purified virus preparation showing isometric CMV particles (pointed at by arrow heads) stained with $2 \%$ uranyl acetate and observed at a magnification of X 60,000 . Scale-bar represents $50 \mathrm{~nm}$.

Detection by real-time reverse transcriptionpolymerase chain reaction (qRT-PCR)

qRT-PCR was performed on total RNA extracted from $N$. glutinosa leaf samples separately infected with CMV- wild tobacco and CMV-cucumber isolates using a pair of sequence-specific primers in the coat protein gene. Analysis of the qRT-PCR result indicated that positive reaction was only obtained with each of the two samples harboring either CMV-wild tobacco or CMV-cucumber isolate and negative reaction with healthy plants, as evidenced by amplification of the target sequence as compared to phosphate buffer mock-inoculated healthy sample which gave a negative reaction as evidenced by the amplification (Green-A and Green-B) and melting curves (Figure 5).

\section{Molecular studies}

\section{Nucleotide sequence}

Nucleotide sequencing of the coat protein gene of both isolates was carried out on the corresponding purified PCR product. The nucleotide sequence of CMV-wild tobacco and CMV-cucumber coat protein gene generated were accepted in the GenBank nucleotide sequence database and given an accession number of LT706517 (CMV-wild tobacco) and LT669766 (CMV-cucumber).
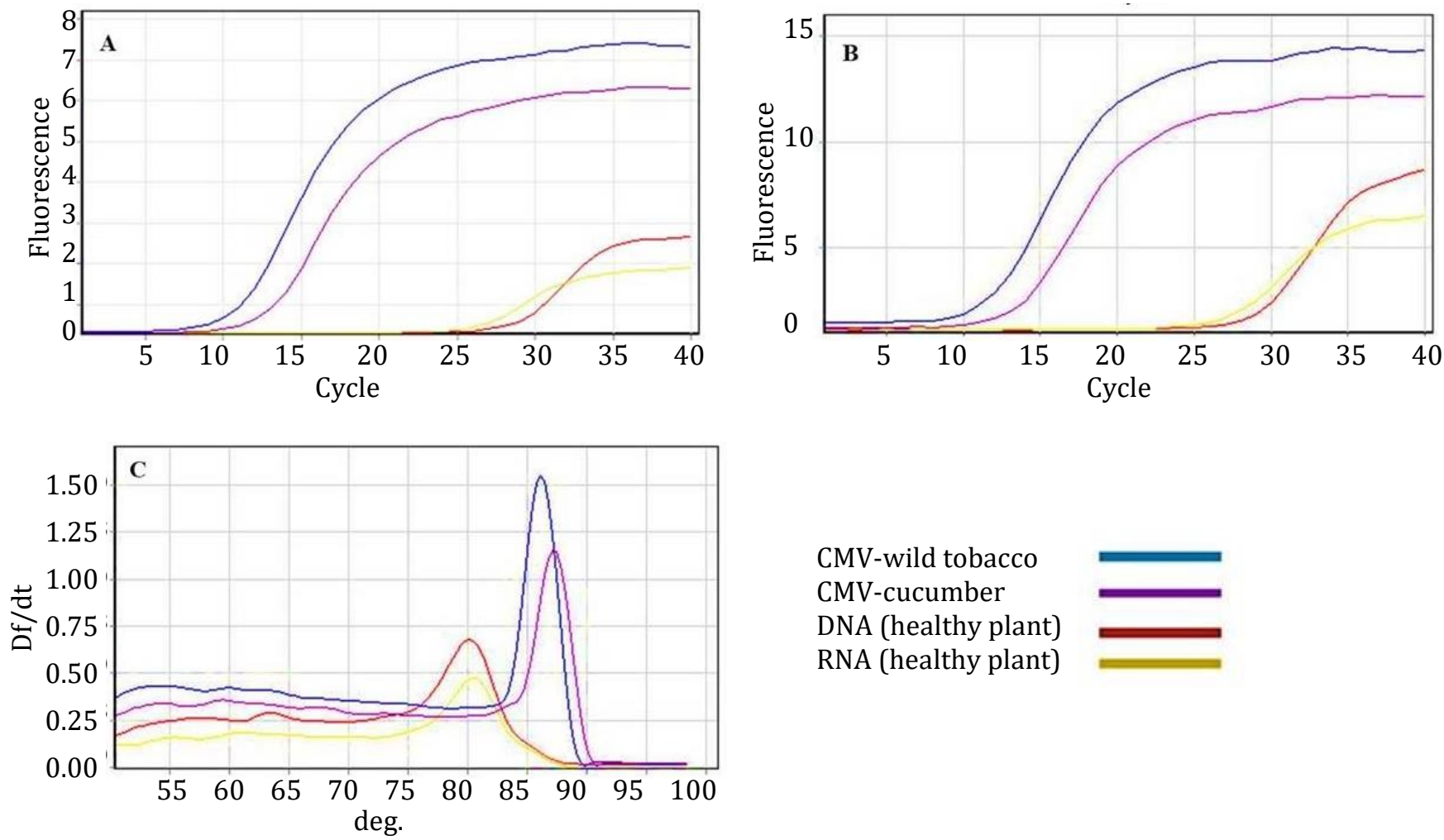

CMV-wild tobacco

CMV-cucumber

DNA (healthy plant)

RNA (healthy plant)

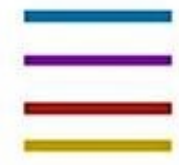

Figure 5. Standardisation of qRT-PCR for the detection of CMV, showing positive reaction with CMV-wild tobacco, CMV-cucumber and negative reaction with DNA-healthy plant and RNA-healthy plant, according to amplification curves. Green A (A); Green-B (B) and Melting curve (C). 
Coat protein nucleotide sequence alignment and phylogenetic relationship analysis among CMV-wild tobacco and CMV-cucumber and several isolates of the same virus kept in GenBank

After partial sequence of CMV coat protein gene of both CMV-wild tobacco (479 nucleotide long) and CMVcucumber (469 nucleotide long) isolates was separately determined, and sequences edited and analysed using Chromas Pro-Version 1.34 software (Seng et al., 2009; Mourembou et al., 2016). Sequences had been submitted to GenBank Database, accession No. LT669766 for CMV-cucumber isolate and accession No. LT706517 for CMV-wild tobacco isolate. The phylogenetic tree was developed using numerous different sequences obtained from the GenBank in order to investigate the similarity of the two isolates with others. Multiple alignment for cDNA sequences of the two CMV isolates, CMV-wild tobacco and CMVcucumber with those of $27 \mathrm{CMV}$ isolates (representing subgroup I (A and B) and II) retrieved from the GenBank made available through the NCBI was conducted using ClustalW software program version 1.82 http://www.ebi.ac.uk./clustalw/, (Thompson et al., 1994). The percentage of similarity was calculated using SIAS software programme by the pairwise method and found to vary among isolates with the two isolates (CMV-wild tobacco and CMV-cucumber) investigated here being closely related and fall within subgroup II. The highest identity and similarity percentage was scored between CMV-wild tobacco (Accession number, LT706517) and CMV-cucumber (Accession number, LT669766) isolate and the Indian CMV isolate, AL (Accession number, AJ58086) with a similarity percentage of $97.07 \%$ and $98.54 \%$, respectively. The corresponding highest similarity between $\mathrm{CMV}$-wild tobacco and CMV-cucumber isolates and the American isolate, 2A1-A, (Accession number, AJ271416) belonging to subgroup IB was 77.99 and $75.19 \%$, in the order given. In contrast, the two isolates differed in similarity with the Ban isolate (Accession number, U43888) belonging to subgroup IA, with a value of 77.49 and $76.24 \%$, respectively (Figure 6).

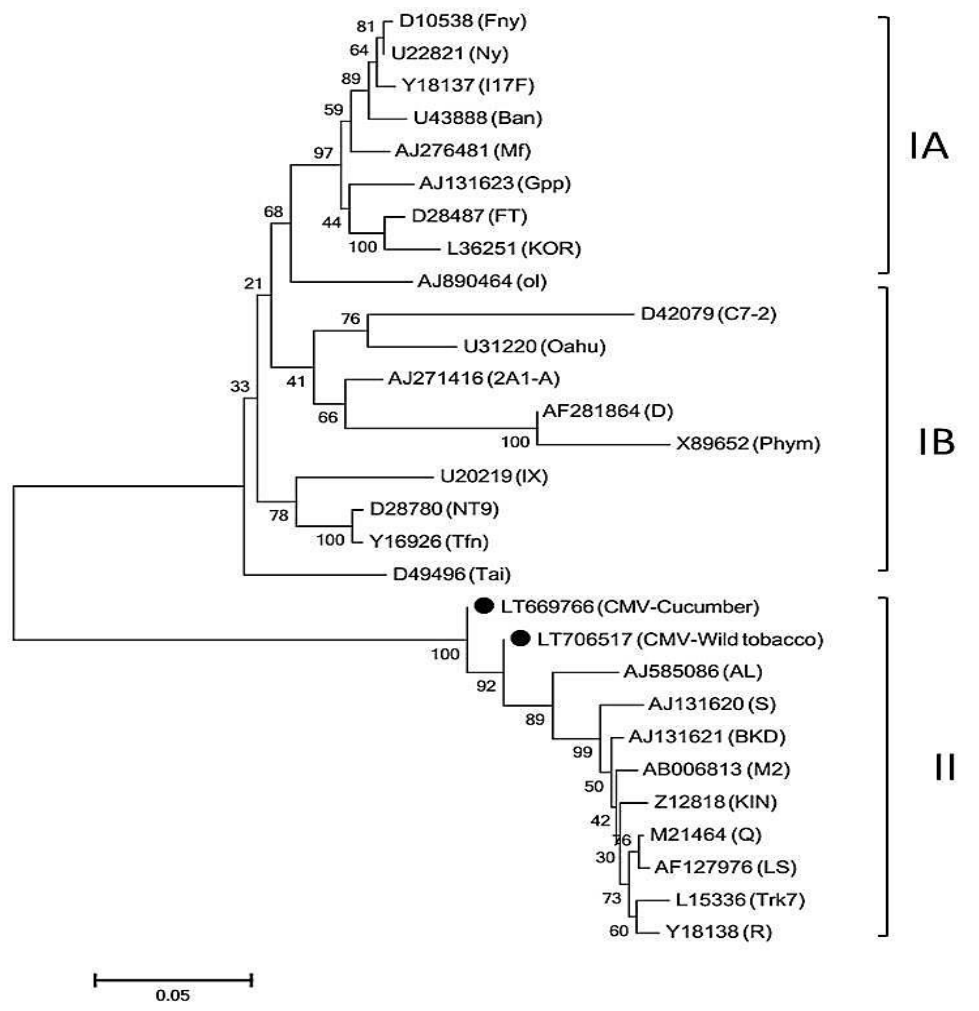

Figure 6. A phylogenetic tree demonstrating the evolutionary relationship among the two CMV isolates, CMV-wild tobacco and CMV-cucumber, investigated here and 27 different CMV entries kept in the GenBank database on the basis of partial nucleotide sequence of coat protein gene using MEGA 6. The tree was constructed using Neighborhood Joining method and Kimura 2-parameter model with bootstrap resampling of 1000 replicates. Value of bootstrap are shown next to branches. 


\section{DISCUSSION}

While characterisation of CMV variations in Egypt was the objective of several investigations (Sofy and Soliman, 2011; Megahed et al., 2012), it was necessary to through further light in this study on the variability of this virus. The results obtained here widens this variability on the basis of cytological, histological changes and molecular relationships.

The crystalline cytoplasmic inclusion bodies induced by the two CMV isolates and visualized in the epidermal cells of infected $N$. glutinosa leaves are identical to those reported by many other researchers (Gerola et al., 1965; Honda and Matsui, 1974; Francki, 1985; Zambolim et al., 1994; El-Baz, 2004; Megahed, 2008; Zitter and Murphy, 2009; Taha, 2010).

Electron microscopy has revealed that infection with CMV isolates have caused a great deal of damage at the organellar level where large number of chloroplasts showing abnormality in terms of swelling, lysis of starch grains, damage to grana and marked disorganisation of lamellae. These results were in agreement with those of Honda and Matsui (1974) and Mochizuki and Ohki (2011). CMV-wild tobacco isolate caused changes in cell wall structure with serration on both sides, while cells infected with CMV-cucumber showed crimpy shape of cell wall with less serration. No such findings have been reported before.

The partially purified virus preparation showing an absorption spectrum characteristic to a nucleoprotein and its spectrophotometrical data (A260/A280) and (Amax/Amin) obtained fell into the range previously reported for CMV by Gibbs and Harrison (1970) and Tomlinson et al. (1973). The slight differences observed in absorbance ratio as well as yield of virus between the present study and those reported in the literature for CMV is likely to be due to experimental errors and/or the nature of the propagative host used. The presence of numerous spherical particles of 28 $\mathrm{nm}$ in diameter each in the partially purified preparation as evidenced by electron microscopy correspond with those reported by other investigators (Tidona and Darai, 2001; Hull, 2002).

The CP gene of CMV isolates was successfully amplified using qRT-PCR and a total RNA preparation from the CMV propagative host $N$. glutinosa as template. When sequence alignment and phylogenetic analysis of CP gene nucleotide sequence of CMV-wild tobacco and CMV-cucumber compared with those of 27 various $\mathrm{CMV}$ isolates classified to $\mathrm{CMV}$ subgroups IA, IB and II, deposited in GenBank and identified from different locations and environments (Sofy and Soliman, 2011). The highest similarity percentage was observed between CMV-wild tobacco and CMVcucumber isolates and the Indian isolate (AL) belonging to subgroup II. The similarity percentage revealed was $97.07 \%$ and $98.54 \%$, respectively confirming that the two isolates belong to subgroup II. To the best of our knowledge, according to the available literature, this is the first report in Egypt where CMV isolates belonging to subgroup II have been obtained.

\section{CONCLUSION}

Characterisation of two Egyptian isolates (CMV-wild tobacco and CMV- cucumber) was carried out on the basis of cytological, histopathological, electron microscopy, shape and size of partially purified virus particles, qRT-PCR and Phylogenetic tree. Alignment of $\mathrm{CP}$ gene nucleotide sequence and phylogenetic relationship analysis confirmed that the two isolates (CMV-wild tobacco and CMV- cucumber) belonged to subgroup II.

\section{REFERENCES}

Aglave, B. A., M. Krishnareddy, F. S. Patil and M. S. Andhale. 2007. Molecular identification of a virus causing banana chlorosis disease from Marathwada region. International Journal of Biotechnology and Biochemistry, 3: 13-24.

Ashby, J. W. 1977. Infection of karaka (Corynocarpus laevigatus J. R. \& G. Forst.) by cucumber mosaic virus. New Zealand Journal of Agricultural Research, 20: 533-34.

Daniels, J. 1992. Characterization of Cucumber Mosaic Virus Isolates from California. Plant disease, 76: 1245-50.

Dheepa, R. and S. Paranjothi. 2010. Transmission of Cucumber Mosaic Virus (CMV) infecting banana by aphid and mechanical methods. Emirates Journal of Food and Agriculture, 22: 117-29.

Dietzgen, R. G., B. Callaghan, C. M. Higgins, R. G. Birch, K. Chen and Z. Xu. 2001. Differentiation of peanut seedborne potyviruses and cucumoviruses by RTPCR. Plant disease, 85: 989-92.

El-Baz, R. M. 2004. Physicochemical, physiological and 
histopathological studies on cucumber mosaic virus, Helwan University.

El-Borollosy, A. M. and H. M. A. Waziri. 2013. Molecular characterization of a cucumber mosaic cucumovirus isolated from lettuce in Egypt. Annals of Agricultural Sciences, 58: 105-09.

Francki, R. I. B. 1985. The Plant Viruses: Polyhedral virions with tripartite genomes. Plenum Press: New York.

Gerola, F. M., M. Bassi and G. Belli. 1965. Some observations on the shape and localization of different viruses in experimentally infected plants, and on the fine structure of the host cells. II. nicotiana glutinosa systemically infected with cucumber mosaic virus, strain y. Caryologia, 18: 567-97.

Gibbs, A. J. and B. D. Harrison. 1970. Cucumber Mosaic Virus. pp. 14.

Honda, Y. and C. Matsui. 1974. Electron microscopy of cucumber mosaic virus-infected tobacco leaves showing mosaic symptoms. Phytopathology, 64: 534-39.

Hull, R. 2002. Purification and Composition of Plant Viruses Matthews' Plant Virology. Elsevier Academic Press. London, UK. pp. 75-107.

Kimura, M. 1980. A simple method for estimating evolutionary rates of base substitutions through comparative studies of nucleotide sequences. Journal of Molecular Evolution, 16: 111-20.

Martelli, G. P. and M. Russo. 1984. Use of thin sectioning for visualization and identification of plant viruses. Methods in Virology, 8: 143-224.

Medina, V., G. Rodrigo, T. Tian, M. Juarez, V. V. Dolja, M. Angeles Achon and B. W. Falk. 2003. Comparative cytopathology of Crinivirus infections in different plant hosts. Annals of Applied Biology, 143: 99-110.

Megahed, A. A. 2008. Effect of antiviral proteins produced by bacterial and fungal isolates on some viruses infecting vegetable crops, Ain Shams University.

Megahed, A. A., K. A. E. Dougdoug, B. A. Othman, S. M. Lashin, M. A. Ibrahim and A. R. Sofy. 2012. A new Egyptian satellite strain of cucumber mosaic cucumovirus. International Journal of Virology, 8: 240-57.

Mochizuki, T. and S. T. Ohki. 2011. Single amino acid substitutions at residue 129 in the coat protein of cucumber mosaic virus affect symptom expression and thylakoid structure. Archives of virology, 156: 881-86.

Mourembou, G., J. Rathored, J. B. Lekana-Douki, A. Ndjoyi-Mbiguino, F. Fenollar, C. Michelle, P. E. Fournier, D. Raoult and J. C. Lagier. 2016. Noncontiguous finished genome sequence and description of Kallipyga gabonensis sp. nov. New Microbes and New Infections, 9: 15-23.

Noordam, D. 1973. Identification of plant viruses: Methods and experiments. Center for Agriculture Publishing and Documentation: Wageningen, The Netherlands.

Nour El-Din, H., R. Salem and K. Abdalla. 2013. Cloning and characterization of cucumber mosaic virus coat protein gene from infected banana plants in Egypt. Egyptian Journal of Genetics and Cytology, 42: 151-61.

Owen, J., M. Shintaku, P. Aeschleman, S. B. Tahar and P. Palukaitis. 1990. Nucleotide sequence and evolutionary relationships of cucumber mosaic virus (CMV) strains: CMV RNA 3. Journal of General Virology, 71: 2243-49.

Rabie, M., C. Ratti, M. Calassanzio, E. A. Aleem and F. A. Fattouh. 2017. Phylogeny of Egyptian isolates of Cucumber mosaic virus (CMV) and Tomato mosaic virus (ToMV) infecting Solanum lycopersicum. European Journal of Plant Pathology, 149: 219-25.

Roossinck, M. J. 2002. Evolutionary history of cucumber mosaic virus deduced by phylogenetic analyses. Journal of Virology, 76: 3382-87.

Sastry, K. S., B. Mandal, J. Hammond, S. W. Scott and R. W. Briddon. 2019. Encyclopedia of plant viruses and viroids. Springer: India.

Seng, P., M. Sarih, C. Socolovschi, N. Boudebouch, M. Hassar, P. Parola, D. Raoult and P. Brouqui. 2009. Detection of anaplasmataceae in ticks collected in Morocco. Clinical Microbiology and Infection, 15: 86-87.

Shevchenko, T. P., O. V. Tymchyshyn, E. AlDalain, A. S. Bysov, I. G. Budzanivska, O. V. Shevchenko and V. P. Polishchuk. 2015. The first evidence of subgroup IB isolates of Cucumber mosaic virus in Ukraine. Biopolymers and Cell, 31: 57-62.

Sialer, M. M. F., F. Cillo, L. Barbarossa and D. Gallitelli. 1999. Differentiation of cucumber mosaic virus subgroups by RT-PCR RFLP. Journal of Plant Pathology, 81: 145-48.

Sofy, A. R. and A. M. Soliman. 2011. Molecular 
identification of a Cucumber mosaic virus subgroup I Egyptian isolate from geranium based on bioinformatics analysis of CP gene sequence. Egyptian Journal of Virology, 8: 178-94.

Sulistyowati, E., N. Mitter, S. Bastiaan-Net, M. J. Roossinck and R. G. Dietzgen. 2004. Host range, symptom expression and RNA 3 sequence analyses of six Australian strains of Cucumber mosaic virus. Australasian Plant Pathology, 33: 505-12.

Suzuki, M., S. Kuwata, J. Kataoka, C. Masuta, N. Nitta and Y. Takanami. 1991. Functional analysis of deletion mutants of cucumber mosaic virus RNA3 using an in vitro transcription system. Virology, 183: 10613.

Taha, M. A. T. 2010. Biological control of Cucumber mosaic virus (Cucumovirus) by certain local streptomycetal isolates, Ain Shams University.

Takeshita, M., N. Shigemune, K. Kikuhara, N. Furuya and Y. Takanami. 2004. Spatial analysis for exclusive interactions between subgroups I and II of Cucumber mosaic virus in cowpea. Virology, 328: 45-51.

Tamura, K., G. Stecher, D. Peterson, A. Filipski and S. Kumar. 2013. MEGA6: Molecular Evolutionary Genetics Analysis Version 6.0. Molecular Biology and Evolution, 30: 2725-29.

Thompson, J. D., D. G. Higgins and T. J. Gibson. 1994.
CLUSTAL W: Improving the sensitivity of progressive multiple sequence alignment through sequence weighting, position-specific gap penalties and weight matrix choice. Nucleic Acids Research, 22: 4673-80.

Tidona, C. A. and G. Darai. 2001. The Springer Index of Viruses. Springer-Verlag: Berlin Heidelberg.

Tomlinson, J. A., A. L. C. Elizabeth, M. Faithfull and M. J. W. Webb. 1973. Purification and serology of the W strain of cucumber mosaic virus. Annals of Applied Biology, 74: 181-89.

Verma, N., B. K. Mahinghara, R. Ram and A. A. Zaidi. 2006. Coat protein sequence shows that Cucumber mosaic virus isolate from geraniums (Pelargonium spp.) belongs to subgroup II. Journal of Biosciences, 31: 47-54.

Wagih, E. E., M. M. Zalat and M. A. Kawanna. 2021. Partial Characterisation of Two Isolates of Cucumber mosaic virus (CMV). Scientific Journal of Agricultural Sciences, 3.

Zambolim, E. M., M. I. T. Assis, L. Zambolim, J. A. Venturia and M. G. de Carvalho. 1994. Natural infection of banana cultivar Prata (AAB) by cucumber mosaic virus in the state of Minas Gerais, Brazil. Fitopatologia Brasileira, 19: 483-84.

Zitter, T. A. and J. F. Murphy. 2009. Cucumber mosaic virus. Plant Health Instructor.

\section{CONFLICT OF INTEREST}

The authors declare that they have no conflicts of interest.

\section{AUTHORS CONTRIBUTIONS}

EEW proposed the scientific ideas and revised the final manuscript, EEW, MAK, MMZ designed the study. MAK, MMZ performed the experiments, data analysis, wrote the first draft of manuscript. All authors have read and approved the final version of manuscript.

Publisher's note: EScience Press remains neutral with regard to jurisdictional claims in published maps and institutional affiliations.

Open Access This article is licensed under a Creative Commons Attribution 4.0 International License, which permits use, sharing, adaptation, distribution and reproduction in any medium or format, as long as you give appropriate credit to the original author(s) and the source, provide a link to the Creative Commons license and indicate if changes were made. The images or other third-party material in this article are included in the article's Creative Commons license, unless indicated otherwise in a credit line to the material. If material is not included in the article's Creative Commons license and your intended use is not permitted by statutory regulation or exceeds the permitted use, you will need to obtain permission directly from the copyright holder. To view a copy of this license, visit http://creativecommons.org/licenses/by/4.0/. 